\title{
The Influence of Transformational Leadership and Organizational Commit- ment on Organizational Citizenship Behavior with Achievement Motivation as Intermediary Variable
}

\author{
Novitta *, Ahmad Suriansyah, Ngadimun \\ Master Program of Education Management, Universitas Lambung Mangkurat, Banjarmasin 70123 \\ Indonesia
}

\section{Article history:}

Submission November 2020

Revised February 2021

Accepted March 2021

*Corresponding author:

E-mail: novittaz@gmail.com

\begin{abstract}
This quantitative study aims to find out: (1) description about transformational leadership, organizational commitment, achievement motivation and whether there is (2) a direct influence of transformational leadership on achievement, (3) a direct influence of organizational commitment on achievement motivation, (4) a direct influence of transformational leadership on $\mathrm{OCB},(5)$ a direct influence of organizational commitment on OCB, (6) a direct influence of achievement motivation on OCB, (7) an indirect influence of transformational leadership on OCB through achievement motivation, (8) an indirect influence of organizational commitment on OCB through achievement motivation. Data from 81 respondents in the Office of Education and Culture of South Kalimantan Province were collected using questionnaires and tested for validity and reliability. Analysis on descriptive statistics and path analysis were based on the calculation using SPSS. The results of this study show that (1) transformational leadership, organizational commitment, achievement motivation and OCB are found in the high category, and (2) all hypotheses are accepted, showing that there is an influence of transformational leadership, organizational commitment and achievement motivation on OCB. In general, achievement motivation was the intermediary variable between the transformational leadership and OCB; and organizational commitment and OCB.
\end{abstract}

Keywords: Achievement motivation, organizational commitment, Organizational Citizenship Behavior (OCB) and transformational leadership

\section{Introduction}

The era of the Industrial Revolution 4.0 (Lase, 2019) and society 5.0 (Pereira et al., 2020) require high quality human resources (HR) to be able to take part competitively and comprehensively in all aspects of life (Haynes
\& Fryer, 2000). For this rea-son, efforts to prepare quality human re-sources are a priority for a country (Suriansyah, 2017), (Abu-Doleh, 2012), and (Redman \& Mathews, 1998). To achieve this goal, the implementation of education must be managed based on a quality

\section{How to cite:}

Novitta. (2021). The influence of transformational leadership and organizational commitment on organizational citizenship behavior with achievement motivation as intermediary variable. Journal of K6 Education and Management, 4 (1), 11 - 23. doi: 10.11594/jk6em.04.01.02 
culture (Mosadegh Rad \& Yarmohammadian, 2006) and (Demirbag et al., 2006). A quality culture must start from the highest education providers to class administrators in this case, the teacher with skills mentioned by Gray (2016) so they can produce better quality human resources.

The teacher is still the spearhead and determinant who makes a major contribution to quality learning (Suriansyah, 2011; Suriansyah, 2017; Hasanah et al., 2018; Suriansyah, 2018). A lot of studies have been discussed and elaborated the influence of TQM on the work culture, but mostly are related to organization and businesses (Ali et al., 2014; Baird et al., 2011). Therefore, teachers must have strong achievement motivation and always develop a lifelong learning culture hence the professional growth is continuously high (Munizu, 2014).

Various studies have shown that achievement motivation grows from leadership in good schools that is supported by high work commitment (Aslamiah, 2016; Aslamiah 2015). It seems that leadership, Organizational Citizenship Behavior (OCB) and organizational commitment are the factors that encourage the development of achievement motivation.

On the other hand, achievement motivation, commitment and leadership at the school level are also very dependent on leadership and service, as well as institutional policies at the upper level, in this case the education office, because good policies and services to education personnel will foster commitment and motivation of the implementers (Arcaro, 2005).

The South Kalimantan Provincial Education Office, which is located on Jl. Trikora Banjarbaru, South Kalimantan as a provincial level government agency always tries to carry out its duties and functions as good as possible. Carrying out tasks related to decentralization and reconcentration of authority in the education sector is not a simple and easy task. As an organization, this agency continues to strive to improve the quality of its human resources so that it can provide optimal services for all related parties (Ueno, 2009; 2008). Various limitations and problems in the field necessitate the hard work of this agency's human resources (Dessler, 2011). Employees who have their respective job descriptions are required to show good performance. On the other hand, in carrying out their duties the various limitations that are owned by the employees themselves as well as the limitations of what is expected to be obtained from their profession really require extra role behavior from employees which is known as organizational citizenship behavior (OCB) (Thiagarajan \& Durairaj, 2017).

Employees who have OCB behavior can contribute more in achieving the organization's goals. Unfortunately, based on the observation, there are several indications showing that the OCB of employees has not been optimal. Several things that indicate the not optimal OCB of the employees in the South Kalimantan Provincial Education Office is that there were employees who seem to have so much work that they look overwhelmed but are reluctant or have no initiative to ask for help from other employees and it is rare to find employees who voluntarily offer assistance. Apart from that, in the work environment, there is frequent questionable information circulating. Although this may be can be neglected, in reality it often affects the work atmosphere and is feared to affect the performance of the employees. The situation illustrated above shows that employees tend to be reluctant to carry out voluntary activities in behaviors that exceed formal work requirements.

What causes the inadequate OCB of the employees in the South Kalimantan Provincial Education Office has never been investigated and is not yet known. However, several related studies that have been conducted show that there are several things that influence the OCB behavior of an employee, including the leadership and motivation of the employee. An organizational leader who is able to manage his institution well will support the improvement in employee performance which in turn will increase the chances 
of achieving organizational goals. The organizational leader in his duties carries out a leadership role. According to Terry (2010), leadership is the whole action or activity to influence the willingness of others to achieve common goals. Meanwhile, Stogdill argues that leadership is a process of influencing group activities in the effort to formulate and achieve goals (Sedarmayanti, 2009). In Euis Soliha and Hersugondo's (2008) research they describe that leadership is defined as a process that causes other people to take action to achieve common goals.

One of the leadership styles that are usually used by leaders is the transformational leadership style. Transformational leadership is one of the many leadership styles that are considered more complete and have many advantages, especially in organizational change. According to Burns (1978) transformational leaders gain support, raise enthusiasm and inspire followers, articulate an organizational vision, give attention and encourage the development of a satisfying work relationship. A transformational leader in an organization is expected to show dignity and generate respect for followers so as to make followers feel inspired to follow and show high involvement in supporting the achievement of organizational goals. The effectiveness of transformational leadership in this case will encourage the increase of organizational commitment of the employees. Research by Walumbwa, Wang and Lawler (Suryanto, 2008) shows that transformational leadership is positively related to commitment and job satisfaction. Research by Geijsel and van den Berg (2003) shows that the dimensions of transformational leadership have a positive effect on the commitment and extra effort (OCB) of teachers.

Another thing that influences employee behavior and performance is achievement motivation. Motivation can have a positive or negative effect on employee performance (Fauzilah, 2011). Employee achievement motivation is also influenced by many elements, including: aspirations, abilities, individual/ environmental conditions and the develop- ment efforts made by the leader of the organization. Related research was also carried out by Putri (Putri, 2019), with the results showing that there is a positive effect of achievement motivation on organizational citizenship behavior (OCB) in the employees of PDAM Tirtanadi Cabang Cemara Medan. From some of the research results above, it can also be concluded that there is a relationship between leadership and achievement motivation on employee's OCB.

Employees who have a high organizational commitment to the organization will do anything to achieve the goals of the organization (Strojanovic et al., 2013). Robin and Judge (2017) state that OCB can arise from various factors in the organization, one of them is the high organizational commitment of the employees. Oemar's (Oemar, 2013) research suggests that organizational commitment has a positive and significant effect on OCB. Farzaneh et al. (2014) stated that organizational commitment has a significant effect on OCB. Research that shows the effect of job satisfaction on OCB through organizational commitment as an intermediary variable was conducted by Najafi et al., (Najafi, 2011), (Bateman \& DW, 1983), and (Dimitriades, 2006) which state that organizational commitment mediates job satisfaction with OCB.

The existence of commitment to employees or workers not only can increase employee responsibility, but is also expected to create a sense of belonging to the organization (Lee \& Chen, 2013). Having high motivation supported by organizational commitment is expected to be able to create a conducive work environment and a sense of kinship in the work environment so as to create $\mathrm{OCB}$ behavior in employees (J. Carlos Bou, 2005). OCB's attitude of employees can be seen from the good working relationship between the employees, mutual support for co-workers, completing their work well, not complaining about the additional work charged, and high loyalty to the organization (Kitapci et al., 2013).

Although there are many previous studies have discussed various forms of lead- 
ership and various other independent variables including work motivation and organizational commitment and their effects on performance, motivated by the lack of research related to forms of extra role performance (OCB) and the importance of knowing what affects this extra role behavior, especially in the South Kalimantan Provincial Education Office, the researcher will examine the influence of leadership in this case transformational leadership, which is one type of leadership that can be implemented in government agencies, and organizational commitment to OCB through the achievement motivation of the employees.

\section{Material and Methods \\ Method}

The approach and type of research used in this study was a descriptive method. The analysis tool used was path analysis to estimate the causal effect between variables and the position of each variable in the path either directly or indirectly. This study was intended to obtain an overview of how much influence the research variables namely transformational leadership (X1), and organizational commitment (X2) as the independent variables; achievement motivation $(Z)$ as the intermediary variable; and OCB (Y) as the dependent variable in this research had.

\section{Population}

The populations in this study were all employees in the office of Education and Culture of South Kalimantan Province with a population of 101. While the sample for this study was determined using the formula from Slovin. Based on this formula, using a significance level of $5 \%$, the sample size of this study was 81 respondents.

\section{Data collection}

The research instrument using Likert five scale model questionnaires was developed to collect data on transformational leadership, organizational commitment, achievement motivation and OCB. The research model is shown in Figure 1.

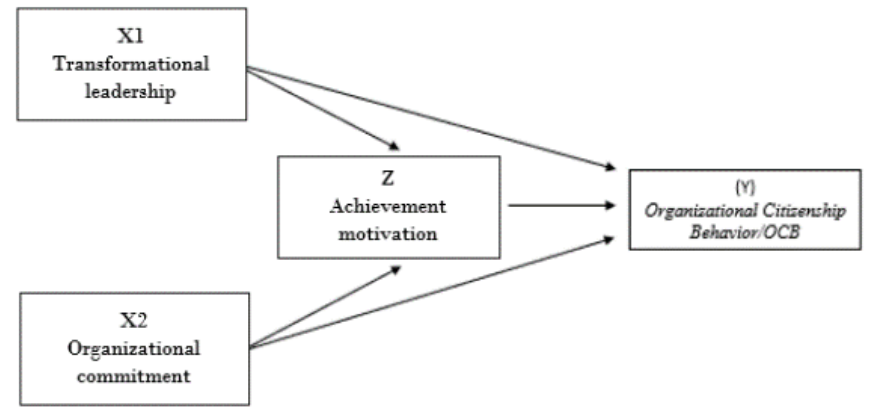

Figure 1. The research-model

The research model using path analysis used to answer the seven research hypotheses namely: H1: There is a direct influence of transformational leadership on achievement motivation; H2: There is a direct influence of organizational commitment on achievement motivation; H3: There is a direct influence of transformational leadership on OCB; $\mathrm{H} 4$ : There is a direct influence of organizational commitment on OCB; H5: There is a direct influence of achievement motivation on $\mathrm{OCB}$;
H6: There is an indirect influence of transformational leadership on OCB through achievement motivation; H7: There is an indirect influence of organizational commitment on OCB through achievement motivation.

\section{Characteristic of respondent}

The numbers of respondents who became the object of this study were 81 people, consisting of 38 respondents or $27 \%$ male and 43 or $53 \%$ female. The lowest age of respondents from the group of less than 20 years was 1 
person and the highest age of respondents from the 31-40 years group was 30 respondents or $37 \%$ of the total respondents. The education level of respondents at most was Strata 1 (S1) with 63 respondents or $77.8 \%$.

\section{Validity and reliability testing}

Reliability test was used to measure the consistency of the measuring instruments. Variables that pass the reliability test can be seen through the Cronbach Alpha value which is $>0.60$. All the four variables in this research met the requirements and can be declared to have passed the reliability test.

\section{Testing requirements analysis}

\section{a. Normality test}

The method used to determine the normality of the data was the Kolmogorov Smirnov method. The result of the test using the IBM SPSS Statistics 21 statistical analysis programshowed that Sig. (2-tailed) 0.357> 0.05 . Based on the results of the normality test, it can be seen that all the variables used in this study were at a significance level of more than 0.05 . Therefore, it can be concluded that the resulting data is at a significance level with a normal distribution.

\section{b. Linearity Test}

The results of value of Sig deviation from linearity aiming $\mathrm{X} 1$ against $\mathrm{Y}=0.870, \mathrm{X} 2$ against $Y=0.843, Z$ against $Y=0.911$. Then it can be concluded the results of the three variable tests on the $Y$ variable indicate that the Sig Deviation from Linearity value are $>0.05$ so that the three variables have a linear relationship.

\section{c. Homogeneity test}

The homogeneity test was done by using the Homogeneity of Variance Test. From the test, it was found that the Sig X1 value of 0,000 ; $X 2$ was 0,000 , and $Z$ was 0,000 , therefore the sig. of the three variables were $<0.05$ so that the data were homogeneous.

\section{d. Multicollinearity}

The results of the test show that the VIF value of X1 was 1,249; X2 value was1.463 and $Z$ was 1.205 , meaning that the VIF value of the three variables were less than ten, therefore it can be concluded that multicollinearity did not occur on the data variable.

\section{Results and Discussion}

The respondents' descriptive statistical analysis of the research variables which is shown in Table 1 includes the mean, standard deviation, and categories. Descriptive data in Table 1 indicates that each variable is in the high category. Interpretation of the path analysis results after the stages of testing the analysis requirements are presented in Table 2 and 3.

Table 1. Mean, standard deviation and categories of research variables

\begin{tabular}{llll}
\hline \multirow{2}{*}{ Variable } & Descriptive & & \\
\cline { 2 - 4 } & Mean & Standard Deviation & Category \\
\hline Transformational Leadership & 81.72 & 10.771 & High \\
\hline Organizational Commitment & 89.02 & 13.996 & High \\
\hline Achievement Motivation & 80.67 & 6.667 & High \\
\hline OCB & 95.28 & 8.808 & High \\
\hline
\end{tabular}

Table 2. Results of path analysis for structure model 1

\begin{tabular}{llll}
\hline \multicolumn{3}{l}{ Structural 1 Transformational Leadership, Organizational Commitment on Achievement Motivation } \\
\hline Variable & Path Coefficient & $t$ & Sig \\
\hline Transformational Leadership & 0.168 & 1.513 & 0.042 \\
\hline Organizational Commitment & 0.412 & 4.021 & 0.000 \\
\hline
\end{tabular}


Table 3. Results of path analysis for structure model 2

Structural 2 Transformational Leadership, Organizational Commitment and Achievement Motivation on OCB

\begin{tabular}{llll}
\hline Variable & \multicolumn{1}{c}{ Path Coefficient } & $t$ & Sig \\
\hline Transformational Leadership & 0.247 & 2.267 & 0.026 \\
\hline Organizational Commitment & 0.538 & 5.669 & 0.000 \\
\hline Achievement Motivation & 0.651 & 7.620 & 0.000 \\
\hline
\end{tabular}

Table 4. Summary of $\mathrm{H}_{1}-\mathrm{H}_{5}$ hypotheses testing decisions

\begin{tabular}{llc}
\hline Hypothesis & Sig & Decision \\
& & Accepted \\
\hline $\begin{array}{l}\text { HiThere is an influence of transformational leadership on achievement } \\
\text { motivation }\end{array}$ & 0.042 & Accepted \\
\hline $\begin{array}{l}\mathrm{H}_{2}: \text { There is an influence of organizational commitment on achieve- } \\
\text { ment motivation }\end{array}$ & 0.000 & Accepted \\
\hline $\mathrm{H}_{3}:$ There is an influence of transformational leadership on OCB & 0.026 & Accepted \\
\hline $\mathrm{H}_{4}:$ There is an influence of organizational commitment on OCB & 0.000 & Accepted \\
\hline $\mathrm{H}_{5}:$ There is an influence of achievement motivation on OCB & 0.000 & \\
\hline
\end{tabular}

Table 5. Summary of $\mathrm{H}_{6}$ and $\mathrm{H}_{7}$ hypotheses testing decisions

\begin{tabular}{|c|c|c|c|}
\hline \multirow[b]{2}{*}{ Hypothesis } & \multicolumn{2}{|c|}{ Path Coefficient } & \multirow[t]{2}{*}{ Decision } \\
\hline & Direct & Indirect & \\
\hline $\begin{array}{l}\mathrm{H}_{6} \text { : There is an indirect influence of transformational lead- } \\
\text { ership on OCB through achievement motivation }\end{array}$ & 0.746 & 0.089 & Accepted \\
\hline $\begin{array}{l}\mathrm{H} 7: \text { There is an indirect influence of organizational com- } \\
\text { mitment on OCB through achievement motivation }\end{array}$ & 0.699 & 0.168 & Accepted \\
\hline
\end{tabular}

The path analysis results shown in Table 2 and Table 3 are to answer the five research hypotheses formulated. The decisions of the analysis results are presented in Table 4 and Table 5. Table 4 summarizes the decisions for hypothesis 1 through hypothesis 5 . The critical significance value is less than 0.05 , and then the hypothesis is accepted. Table 5 summarizes the decisions of testing hypothesis 6 to hypothesis 7 , showing that there is indirect influence of transformational leadership and organizational commitment on OCB through achievement motivation. Based on the results of the analysis in the tables above this study has successfully found intervariable influences that can be explained as follows.

\section{The influence of transformational leadership on achievement motivation}

The results of this study that show that there is a significant influence of transformational leadership on achievement motivation is in line with research on transformational leadership with the title Transformational Leadership Style and Compensation for Employee Performance: With Achievement Motivation as Intervening Variable conducted by Adiarso (Adiarso, 2017). This study found that transformational leadership style affects achievement motivation. This means that if the transformational leadership style is applied properly, it will increase employee achievement motivation. This means that there is a positive and significant influence 
between the variables of transformational leadership style on achievement motivation.

Based on the description above, there is a relationship between the head of the office's transformational leadership and achievement motivation. This means that the better the leadership of the office head, the better the motivation for the achievement of the employees. Likewise, on the other hand, the worse the office leadership, the lower the employee's motivation for achievement.

Furthermore, Posner and Kauzes and (Aslamiah, 2016) formulate five steps that can be taken to become transformational leaders, namely: (1) questioning current practices, (2) inspiring a common vision, (3) helping others to act, (4) demonstrating or practicing how to realize the new vision, and (5) giving full support.

\section{The influence of organizational commitment on achievement motivation}

Based on the results of this study, it was found that there is a direct influence of organizational commitment on achievement motivation of employees the Office of the Education and Culture of the Province of South Kalimantan. The result of this study confirms the finding of Arifah and Romadhon's research (Arifah \& Romadhon, 2015) which states that organizational commitment influences motivation with a positive coefficient which means that the increase in organizational commitment, the more motivation increases. This condition occurs because employees who have organizational commitment feel that they love the organization so that they motivate themselves to work and perform better for the progress of their organization.

The research results from Marewa et al. (2018) also found that organizational commitment has a positive influence of 78.7 on motivation. Likewise, Badjuri's research (Badjuri, 2009) found that organizational commitment influenced job satisfaction through motivation as an intervening variable. Organizational commitment is a combination of attitude and behavior. Someone with organizational commitment will be motivated to work as good as possible in an organization as an effort to achieve the common goals (Tranggono et al., 2008). The high level of achievement motivation in employees can be seen from their commitment to the organization, when people like their work for the job itself, they often feel committed to the organization, as a consequence, it makes work possible (Goleman, 2003).

From the description above, it can be concluded that the level of achievement motivation of employees is very much influenced by factors within a person which encourage the individual to do something and is an internal driving force to achieve certain goals. If the motivation to do the job is high, she/he will be more enthusiastic at work and from this from high organizational commitment may emerge. In other words, the level of organizational commitment of an employee can influence the employee's achievement motivation.

\section{The influence of transformational leadership on $O C B$}

Based on the results of this study it was found that there was a direct influence of transformational leadership on OCB. The results of this study support the findings of previous research conducted by Maulida et al. (2019) and Aslamiah (2014) which concluded that transformational leadership contributes positively and significantly to OCB of MIN teachers in Banjarmasin. This result is also in line with the findings of Pebriani et al. (2019) that there is a relationship between the transformational leadership of school principals and OCB of junior high school teachers in Tanjung Redeb. According to Podsakoff et al. (2000) support these results and suggest that organizations benefit from encouraging employees to be directly involved in OCB as this can increase productivity, efficiency and customer satisfaction (Ahmad, 2016).

According to Robbins and Judge (2017) leadership is the ability to influence a group to achieve a vision or set of goals and in leadership theory followers view leaders as individuals who inspire their followers through words, various ideas, and their behavior, the leader in this case the head of office motivate 
followers, in this case the employees, to work loyally and sacrifice personal interests for the sake of the organization to do tasks that are not listed in the description of the employees' work, the facts show that organizations that have such employees, have a better result. This is consistent with the research of Moghimi et al. (2013), Cahyadi 2018), Hutahayan et al. (2013) which states that transformational leadership has a positive and significant influence on OCB.

\section{The influence of organizational commitment on $O C B$}

Based on the results of this study, it was found that the direct influence of employee organizational commitment on the OCB of the employees of the Office of Education and Culture of South Kalimantan Province. This study confirms the results of research by Maulida, Suriansyah and Ngadimun (2019) which found that organizational commitment contributed positively and significantly to the OCB of MIN teachers in Banjarmasin by $75.5 \%$.

The results of this study are supportedby previous research conducted by Arimbawa (Arimbawa, 2016) which concluded that organizational commitment has a positive and significant effect on teachers' OCB. The same thing was also reported by Iswan (2016) and Normianti et al. (2019), based on the fact that organizational commitment has a positive and significant impact on OCB.

OCB can arise from various factors in the organization, including those caused by employee job satisfaction and high organizational commitment (Robbins \& Judge, 2017; Sharma \& Bajpai, 2010). Employee commitment is one of the most important things that determine the success or failure of an organization to achieve its goals (Andrew, 2017).

The characteristics of organizational commitment include emotional attachment and a sense of pride in the organization, without intention to move from the organization, loyal to the organization and the obligation and responsibility to survive in the organization (Radosavljević et al., 2017) Organizational commitment will greatly support OCB behavior of employees to always do things that are positive and very beneficial to the organization even though they are not the main task of the employees but indirectly will greatly affect the continuity and reputation of the organization.

From the description above, it is clear that high organizational commitment from each employee will increase individual OCB. If individual OCB increases, teamwork performance tends to increase which in turn will improve the performance of the organization therefore it will easily achieve the vision and mission that has been set.

\section{The influence of achievement motivation on $O C B$}

Based on the results of this study, it was found that there is a direct influence of achievement motivation on OCB. This is in line with the results of Putri's research analysis (Putri, 2019) which found that achievement motivation influenced OCB by $45.3 \%$. The results of this study confirm the research conducted by Darmawati (Organ, 2006) which shows that the need for achievement becomes an independent variable that has a direct influence on OCB.

Motivation is a set of factors that can generate, direct and maintain a person's behavior to choose a certain path in achieving goals (Sugiyono, 2012). One form of motivation is achievement motivation. A motivated person, a person who makes substantial efforts to support the production goals of his unit of work and the organization in which he works. A person who is not motivated, giving only minimum effort in terms of work, he will not be willing to put extra effort beyond the demands of his job. On the other hand, someone who is motivated will be willing to do work outside of his duties or OCB.

McClelland (1987) considers need for achievement (n-ach) to be a mental virus. This mental virus is a thought related to how to do something well, faster, more efficiently than what has been done before. Further he explains that achievement motivation is the desire to get something done in order to achieve 
a standard of success, and to make an effort with the aim of achieving success.

\section{The indirect influence of transformational leadership on OCB through achievement mo- tivation}

Based on the results of this study, it is found that there is an indirect influence of transformational leadership on OCB through the achievement motivation. The value of $R$ Square which is 0.443 indicates that the indirect influence of transformational leadership on OCB through achievement motivation of the employees of the Office of Education and Culture of South Kalimantan Province is 44 . $30 \%$ while the remaining $55.70 \%$ is the influence of other variables. Based on the results of the calculations, it is known that there is an indirect influence of transformational leadership variable (X1) to OCB (Y) through achievement motivation (Z) of 0.089 .

The results of this study are in accordance with Ivancevich et al explanation (Ivancevich et al., 2022; Hasanah \& Suriansyah, 2019) research that there is a relationship between work motivation and OCB of teachers of SMK Muhammadiyah. Based on the opinion of Kusumajati (2014), the contribution of motivation to employees' OCB is more dominant if it is from within a person that is: (a) able to work, (b) moral, (c) s sense of togetherness in group life, and (d) achievement and products -worker activity. This study explains that OCB is widely seen as a factor that contributes to the work of the organization as a whole.

Fiftyana and Sawitri (2018) in their research explained that OCB has a relationship with emotional intelligence, that $\mathrm{OCB}$ is a tool for achievement in teacher duties, when work performance becomes a motive, organizational citizen behavior appears, because this behavior is deemed necessary for task success. Motivation encourages someone to see the tasks that are developed more thoroughly, thus forming OCB. This means that the greater the contribution of teacher work motivation is, the higher the teacher's OCB is.

The results of this study are in line with the research of Pebriani et al. (2019) which found that there is a positive and significant relationship between transformational leadership and teacher OCB through motivation. This can be seen from the path coefficient value of 0.157 which proves a positive development. With the availability of sufficient motivating and hygienic factors, the principal indirectly spurs motivation and creates OCB behavior. The results of this study are reinforced by Ahmad et al (Ahmad, 2016) which state that a leader needs to provide a complete package of motivation.

The results of the research show that there is an indirect influence of transformational leadership on employee OCB through achievement motivation of the employees of the Office of Education and Culture of South Kalimantan Province. This influence has a meaning that the higher the level of transformational leadership and employee achievement motivation is the higher OCB behavior of the employees will be (Lambert et al., 2008).

\section{The indirect influence of organizational com- mitment on OCB through achievement moti- vation}

Based on the results of this study, it is found that there is an indirect influence of organizational commitment on OCB through the achievement motivation. The value of $R$ Square which is 0.511 indicates that the indirect influence of organizational commitment on OCB through achievement motivation is $51.10 \%$ while the remaining $48.90 \%$ is the influence of other variables. Based on the results of the calculations, it is known that there is an indirect influence of organizational commitment (X2) to OCB (Y) through achievement motivation $(Z)$ of 0.168 .

The results of Ristiana's (Ristiana, 2013) research state that organizational commitment has a positive and significant effect on employee OCB at Bhayangkara Trijata Hospital in Denpasar. The research conducted by Anshori (2013) and Khan et al. (2013) found that there is a relationship between organizational commitment and OCB. Based on the analysis of the regression correlation coefficient between organizational commitment 
and $\mathrm{OCB}$, it shows a significant positive relationship. This means that the higher the value of an employee's organizational commitment, the higher the OCB value of the employee. Rehan et al. (Rehan \& Islam, 2013) revealed that the overall form of commitment significantly influences OCB.

The results of the research show that there is an indirect effect of organizational commitment on employee OCB through the achievement motivation of employees of the South Kalimantan Provincial Education and Culture Office. This influence means that the higher the level of organizational commitment and employee achievement motivation, the higher OCB will be.

\section{Conclusion and Recommendation}

Based on the results of the research analysis and discussion described, this study finds: 1. Transformational leadership, organizational commitment, achievement motivation and OCB employees of the Education and Culture Office of South Kalimantan Province are in the medium and high categories; 2. there is a direct influence of transformational leadership on achievement motivation; 3 . there is a direct influence of employee organizational commitment on achievement motivation; 4 . there is a direct influence of transformational leadership on OCB; 5 . There is a direct influence of employee organizational commitment on OCB; 6 . There is a direct influence of employee motivation on OCB; 7. There is an indirect influence of transformational leadership on OCB through the achievement motivation; and 8 . There is an indirect influence of organizational commitment on OCB through the achievement motivation.

Suggestions that can be given by researchers in accordance with the research that have been carried out are: 1 . all variables in this study ranging from transformational leadership, organizational commitment, achievement motivation and $\mathrm{OCB}$ can continue to be used and even improved for the better; 2 . the head of the office is expected to assist and guide employees in order to maintain and in- crease organizational commitment, achievement motivation and OCB in the organization; and 3. other researchers are suggested to conduct other researches by increasing the same variables in different places. Besides, given that OCB is also influenced by other variables beyond the three variables investigated in this study, subsequent studies also need to be tested on other variables that also contribute to OCB in Education and Culture Office of South Kalimantan Province.

\section{Acknowledgment}

The author's gratitude and appreciation to all parties that have contributed to the research and the completion of this article, especially the advisors and the lecturers of Master Program of Education Management ULM. May Allah SWT grant His blessings for them all.

\section{References}

Abu-Doleh, J. D. (2012). Human resource management and total quality management linkage - rhetoric and reality: Evidence from an empirical study. International Journal of Commerce and Management, 22(3), 219-234.

Adiarso, T. P. (2017). Transformational leadership style and compensation for employee performance: with achievement motivation as an intervening variable (Empirical study at the office of education and culture of batang regency). Proceeding of FEB UNTAG Semarang.

Ahmad, S. W. (2016). Does motivation lead to organizational? A Theoretical Review. Global Journal of Management and Business Research: A Administration and Management, 16, (7), 2249-4588.

Ali, Z. A. (2014). Implementing total quality management concepts to LAND administration system in Pakistan. American Journal of Rural Development, 2, 74-80.

Andrew, A. (2017). Employees' commitment and its impact on organizational performance. (M. D. Wong, Ed.). Asian Journal of Economics, Business and Accounting, 5(2), 1-13.

Anshori, M. I. (2013). Relationship between organizational commitment and job satisfaction on Organizational Citizenship Behavior (OCB) (Case Study at the Surabaya Poltekkes). 42-50.

Arcaro, S. (2005). Quality based education. Yogyakarta: Pustaka Pelajar.

Arifah, D.A.\& Romadhon, C. (2015). The effect of organizational commitment, professional commitment and leadership style on job satisfaction with motivation 
as an intervening variable (Empirical study at a public accounting firm in Semarang). Conference In Business, Accounting, and Management (CBAM), 2(1), 1-10.

Arimbawa, I. P. (2016). The influence of transformational leadership, job satisfaction and organizational commitment to organizational citizenship behavior. EJurnal Manajemen Unud, 5(7), 4367-4393.

Aslamiah. (2014). Contribution of principal leadership and organizational culture on school accreditation at elementary schools in Central Banjarmasin District. Paradigma, Journal of Educational Science, 9(1), 1-10.

Aslamiah. (2015). Developing the elementary school's quality through transformational leadership of the head master. Proceeding of National Seminar PS2DMP Unlam, 1 (2), 111119.

Aslamiah. (2016). Organizational Citizenship Behavior (OCB) of elementary school teacher. Proceeding of National Seminar PS2DMP Unlam, 2(2), 105-111.

Badjuri, A. (2009). The effect of organizational and professional commitment on auditor job satisfaction with motivation as an intervening variable. Kajian Akuntansi, 1(2), 117132.

Baird, K., Hu, K., \& Reeve, R. (2011). The relationships between organizational culture, total quality management practices and operational performance. International Journal of Operations and Production Management, 31, 789814.

Bateman, T., \& DW, O. (1983). Job satisfaction and the good soldier: the relationship of employee commitment: an exploratory study. Journal of Applied Business Research, 16(4), 15- 27.

Burns, J. M. (1978). Leadership (15th ed ed.). New York: Harper \& Row.

Cahyadi, M. (2018). The influence of transformational leadership and organizational commitment to organizational citizenship behavior at Villa Kubu Manggala Seminyak. E-Jurnal Manajemen Unud, 7(2), 614-642.

Demirbag, M., Tatoglu, E., Tekinkus, M. et al. (2006). An analysis of the relationship between total quality management implementation and organizational performance Turkish SMEs. Journal of Manufacturing Technology Management, 17, 829-47.

Dessler, G. (2011). Human resource management (12th ed. ed.). USA: Prentice-Hall.

Dimitriades, Z. S. (2006). Customer satisfaction, loyalty and commitment in service organizations. Management Research News, 29(12), 782-800.

Farzaneh, J., Dehghanpour, A., \& \& Kazemi, F. (2014). The impact of person-job for and person organization fit on
OCB: The mediating and moderating effects of organizational commitment and psychological empowerment. Personnel Review 43(5), 672-691.

Fauzilah, E. A. (2011). The effect of motivation on job performance of state government employees in Malaysia. International Journal of Humanities and Social Science, 1(4), 147-154.

Fiftyana, B., \& \& Sawitri, D. (2018). The relationship between emotional intelligence and Organizational Citizenship Behavior (OCB) in public Elementary School Teachers (SD) in Banyumanik District, Semarang City. Jurnal Empati, 7(1), 110-115.

Geijsel, F., P., S., \& van den Berg, R. (2003). Transformational leadership effects on teachers' commitment and effort toward school reform. Journal of Educational Administration, 41(3), 228-256.

Goleman, D. (2003). Leadership that brings results (First Edition). Jogjakarta: Amara Books.

Gray, A. (2016). The 10 skills you need to thrive in the Fourth Industrial Revolution. World Economic Forum.

Hasanah, R., Suriansyah, A., \& Ngadimun. (2018). Contributions of principals transformational leadership, teacher job satisfaction, organizational citizenship behavior (OCB) in Madrasah Ibtidaiyah (MIN) Banjarmasin, Indonesia. European Journal of Alternative Education Studies, 4(1), 33-56.

Hasanah, R., \& Suriansyah, A. (2019). Relationship of school culture and work motivation with Organizational Citizenship Behaviour (OCB) teacher of muhammadiyah vocational school In Banjarmasin, Indonesia. European Journal of Alternative Education Studies.

Haynes, P., \& Fryer, G. (2000). Human resources, service quality and performance: A case study. International Journal of Contemporary Hospitality Management, 12(4), 240-248.

Hutahayan, B., Astuti, E., Raharjo, K., \& D., H. (2013). The effect of transformational leadership, organizational culture, reward to organizational citizenship of employee behavior at PT Barata Indonesia (Persero). Interdisciplinary Journal of Contemporary Research in Business, 5(6), 466-474.Iswan, I. P. (2016). The influence of transformational leadership, job satisfaction and organizational commitment to organizational citizenship Behavior at PT. BPD Bali. E-Jurnal Manajemen Unud, 5(9), 5923-5948.

Ivancevich, J., Konopaski, R., \& Matteson, M. (2002). Organizational citizenship behavior. Boston: McGraw-Hill.

J. Carlos Bou, I. B. (2005). Total quality management, highcommitment human resource strategy and firm 
performance: an empirical study. Total Quality Management \& Business Excellence, 16(1), 71-86.

Khan, H., Razi, A., Ali, S., \& Asghar, A. (2013). A study on relationship between organizational job commitment, and its determinants among CSRS and Managerial Level Employees of Pakistan (Telecommunication Sector). Interdisciplinary J. Contemporary Res, 3(11), 269-284.

Kitapci, O., Dortyol, I. T., Yaman, Z., \& Gulmez, M. (2013). The paths from service quality dimensions to customer loyalty. Management Research Review, 36(3), 239-255.

Kusumajati, D. A. (2014). Organizational Citizenship Behavior (OCB) of employees at the company. Humaniora, 5(1), 6270.

Lambert, EG., Hogan, NL., \& Griffin, ML. (2008). Being the good soldier: Organizational citizenship behavior and commitment among correctional staff. Criminal Justice and Behavior, 3(1), 56-68. 10.1177/0093854807308853

Lase, D. (2019). Education and Industrial Revolution 4.0. Article.doi: 10.24114/jh.v10i1

Lee, C. \& Chen, C. (2013). The relationship between employee commitment and job attitude and its effect on service quality in the tourism industry. American Journal of Industrial and Business Management, 196-208.

Marewa, Y., Saleh, Y., \& Abduh, T. (2018). The influence of professionalism and organizational commitment on the performance of internal auditors and reward as an intervening variable (Study at the Inspectorate Office of South Sulawesi Province). Indonesian Journal of Business and Management, 1(1), 53-56.

Maulida, H., Suriansyah, A., \& Ngadimun. (2019). Contributions Of Principal Transformational Leadership, Teacher Job Satisfaction, Organizational Commitment To Teacher's Organizational Citizenship Behavior (OCB) In Madrasah. European Journal of Alternative Education Studies, 4(1), 116-122.

McClelland, D. (1987). Human motivation to work. New York: John Wiley and Son.

Moghimi, S., \& Subramaniam, I. (2013). Employees' creative behavior: the role of organizational climate in Malaysian SMEs. International Journal of Business and Management, 8(5), 1-13.

Mosadegh Rad, A., \& Yarmohammadian, M. (2006). A study of relationship between managers' leadership style and employees' job satisfaction. Leadership in Health Services, 19, 11-28.

Munizu, M. (2014). A Study on relationship between tqm practices and competitive advantage: case at basic metal industry in Indonesia. Ausralian Journal of Basic \& Applied Sciences, 8(13), 290-295.
Najafi, S. (2011). Investigating the relationship between organizational justice, psychological empowerment, job satisfaction, organizational commitment and organizational citizenship behavior: An empirical model. African journal of Business Management, 5(13), 5241-5248.

Normianti, H., Aslamiah, \& Suhaimi. (2019). Relationship of transformational leaders of principal, teacher motivation, teacher organization commitments with a performance of Primary School teachers in Labuan Amas Selatan, Indonesia. European Journal of Alternative Education Studies, 5(1), 123-140.

Oemar, Y. (2013). The influence of organizational culture, work ability and organizational commitment on employee Organizational Citizenship Behavior (OCB) at BAPPEDA Pekanbaru City. Journal of Management Application, 65-76.

Organ, D. (2006). Organizational citizenship behavior. It's nature, antecedents, and consequences. California: Sage Publication, Inc.

Pebriani, H., Aslamiah, Saleh, M., \& Sin, I. (2019). The contribution of principal transformational leadership, work motivation, through satisfaction with OCB teachers. Journal of K6, Education, and Management, 2(2), 159-165.

Pereira, A. G., Lima, T. M., \& Charru, F. (2020). Industry 4.0 and Society 5.0: Opportunities and threats. International Journal of Recent Technology and Engineering (IJRTE), 8(5), 118-123.

Podsakoff, P. M., MacKenzie, S. B., Paine, J. B., \& Bachrach, D. G. (2000). Organizational citizenship behaviors: A critical review of the theoretical and empirical literature and suggestions for future research. Journal of Management, 26(3), 513-563.

Putri, V. (2019). The influence of achievement motivation toward organizational citizenship behavior among PDAM Tirtanadi employees cemara branch Medan. Thesis.

Radosavljević, Ž., Ćilerdžić, V., \& Dragić, M. (2017). Employee organizational commitment. International Review, 18-26.

Redman, T., \& Mathews, B. P. (1998). Service quality and human resource management. Personnel Review, 27(1), $57-77$.

Rehan, M., \& Islam, T. (2013). Relationship between organizational commitment and citizenship behavior. World Journal of Management and Behaviorial Studies, 1(1), 24-32.

Ristiana, M. (2013). The effect of organizational commitment and job satisfaction on Organizational Citizenship Behavior (OCB) and employee performance at 
Bhayangkara Trijata Hospital Denpasar. DIE, Journal of Economics and Management Science, 9(1), 57-70.

Robbins, P. S., \& Judge, T. A. (2017). Organizational behaviour (13th ed., vol. 1). Jakarta: Salemba Empat.

Sedarmayanti. (2009). Human resources and work productivity. Bandung: Mandar Maju.

Sharma, J., \& Bajpai, N. (2010). Organizational commitment and its impact on job satisfaction of employees. A comparative study in public and private sector in India. Int. Bulletin of Bus. Admin, 7-19.

Soliha, E., \& Hersugondo. (2008). Effective leadership and organizational change. Economy Focus, 7(2), 83 - 93.

Strojanovic, T., Djokic, A., \& Djokic, S. (2013). Organizational behavior-creative tool for creating value. International Review, 1-2, 112-119.

Sugiyono. (2012). Business research methods. Bandung: Alfabeta.

Suriansyah, A. (2011). Character education in national educational system perspective. Paradigma, Journal of Educational Sciences, 6 (11), 117-130.

Suriansyah, A. (2014). Relationship between school culture, communication, and work commitment on primary school teacher performance. Cakrawala Pendidikan, XXXIII (3), 358-367.

Suriansyah, A. (2017). Implementation of the total quality management model to support quality of work cultures at primary school teacher education programs in
Lambung Mangkurat University Indonesia. Australian Journal of Basic and Applied Sciences, 179-186.

Suriansyah, A. (2018). Teacher's job satisfaction on elementary schools: relation to learning environment. The Open Psychology Journal, 11(1), 123-130.

Suryanto, D. (2008). Distinguish leader. Internet Article.

Terry, G. R. (2010). Management fundamentals (Eleventh Ed.). Jakarta: PT. Bumi Aksara.

Thiagarajan, T., \& Abraham Durairaj, I. Y. (2017). Organisational citizenship behaviour: it's definitions and dimentions. GE-International Journal of Management Research, 5(5), 9-14.

Tranggono, Probo, R., \& Kartika, A. (2008). the influence of organizational and professional commitment on auditor job satisfaction with motivation as an intervening variable (empirical study at a public accountant office in Semarang). Journal of Business and Economy, 15(1), 145152.

Ueno, A. (2008). Which management practices are contributory to service quality? International Journal of Quality $\mathcal{E}$ Reliability Management, 25(6), 585-603.

Ueno, A. (2009). Which management practices are contributory to service quality? International Journal of Quality $\mathcal{E}$ Reliability Management, 26(8), 761-777.

Ueno, A. (2010). What are the fundamental features supporting service quality? Journal of Services Marketing, 24(1), 74-86. 